Polgári Szemle, 16. évf. 1-3. szám, 2020, 333-350., DOI: 10.24307/psz.2020.0720

Vasa László

\title{
Közép-Ázsia: Eurázsiai Gazdasági Unió vagy Övezet és Út?
}

\section{Central Asia: a Eurasian Economic Union or a Belt and Road Initiative?}

Összefoglalás

A Szovjetunió megszúnése után a közép-ázsiai régió geopolitikai szerepe felértékelôdött. Ásványkincsei és Európa és Ázsia közötti kulcsfontosságú földrajzi elhelyezkedése miatt a térség a nagyhatalmak közötti versengés terepévé vált. Tanulmányomban azt vizsgálom meg, mely hatalmak milyen érdekekkel vannak jelen a régióban, és menynyiben szolgálják ezek a törekvések a régió érdekeit. Kína és Oroszország geopolitikai stratégiai érdekeik mentén hangsúlyosan jelen vannak Közép-Ázsiában. A Moszkva által dominált Eurázsiai Gazdasági Unió és a Peking által kezdeményezett Övezet és Út program egyaránt igen aktív a térségben. Oroszország és Kína térségbeli viszonyát elemezve felvetôdik a kérdés, hogy versengésról, együttmúködésrôl vagy együttmúködésen alapuló versenyrôl van szó.

Journal of Economic Literature (JEL) kódok: F02, F15, F53, F55, N40

Kulcsszavak: Közép-Ázsia, Oroszország, Kína, Eurázsiai Gazdasági Unió, Övezet és Út Kezdeményezés, integráció, versengés, coopetition

Dr. VASA LÁszló, vezetô kutató, fôtanácsadó, Külügyi és Külgazdasági Intézet, kutatóprofesszor, Széchenyi István Egyetem (laszlo.vasa@ifat.hu). 
Vasa László: Közép-Ázsia: Eurázsiai Gazdasági Unió vagy Övezet és Út?

\section{Summary}

After the collapse of the Soviet Union, the geopolitical role of the Central Asian region increased. Due to its mineral resources and its key geographical position between Europe and Asia, it has become a field for competition between great powers. The study examines the powers interested in this region and the extent to which these efforts serve the interests of Central Asian countries. The key stakeholders present in Central Asia are China and Russia. Both the Moscow-dominated Eurasian Economic Union and the Beijing-initiated Belt and Road Initiative are highly active in the region. An analysis of the regional relations between Russia and China raises the question whether it is a competition, a cooperation, or a coopetition.

Journal of Economic Literature (JEL) codes: F02, F15, F53, F55, N40

Keywords: Central Asia, Russia, China, Eurasian Economic Union, Belt and Road Initiative, integration, competition, coopetition

\section{BEVEZETÉS}

A Közép-Ázsia fölötti befolyás a 19. századi analógiák alapján az „új nagy játszma” elnevezést kapta. Jelen tanulmány azt vizsgálja, hogy Oroszország és Kína milyen módon igyekszik befolyást szerezni a közép-ázsiai régióban. Szükséges megvizsgálni azt is, egyáltalán létezik-e konkurálás, vagy a két nagyhatalom térségbeli mozgását inkább „coopetition”-nel, azaz együttmúködésen alapuló versengéssel jellemezhetjük?

Általános értelmezés szerint Közép-Ázsia alatt a tengeri kijárattal nem rendelkezô („landlocked”) ázsiai régiót értjük. Ezt a logikát követve, az UNESCO definíciója szerint a közép-ázsiai régióban benne van Kazahsztán, Kirgizisztán, Üzbegisztán, Tádzsikisztán, Türkmenisztán, Mongólia és Afganisztán is (Dani et al., 2005). A 20. században használt szovjet definíció Közép-Ázsiához sorolt egyes kínai területeket - Belsố-Mongóliát, Tibetet és Hszincsiang tartományt - is, azonban nem volt része Kazahsztán, mivel azt Oroszország szerves részének tekintették (Nagy Szovjet Enciklopédia, 2012). Írásomban Közép-Ázsia manapság leginkább elterjedt politikai földrajzi definícióját használom, így a régió alatt öt országot értek: Kazahsztánt, Kirgizisztánt, Tádzsikisztánt, Türkmenisztánt, Üzbegisztánt. ${ }^{1}$ Mindegyik nemrég, a Szovjetunió 1991es összeomlása után függetlenné vált posztszovjet utódállam, és határaik jelenlegi formájukban az elmúlt száz évben alakultak ki (lettek kijelölve) a szovjet rendszer alatt.

A nemzetközi kapcsolatok diszciplínában egy adott térség feletti kontroll megszerzése olyan aszimmetrikus viszonyt jelent, amelyben egy közepes vagy nagyhatalom „kemény” vagy „puha” erejét képes az adott régióra kizárólagosan kiterjeszteni. Ez katonai vagy politikai befolyás lehet, de tágabb megközelítésben értelmezhetjük a gazdasági függőség vagy a kulturális, történelmi kapcsolatok szintjén is, Közép-Ázsia esetében kiegészülve a korábbi intézmények és államigazgatási rendszer fennmaradásával és a megörökölt szövetségi és partnerségi kapcsolatokkal, melyek szintén fontos 
eredôi lehetnek az adott régió ellenôrzésének (Baldwin, 1985; Armitage-Nye, 2007). Közép-Ázsia viszonylatában mind Oroszország, mind Kína esetében egyértelmúen kimutatható az aszimmetrikus, tulajdonképpen kiszolgáltatott viszony (TrevertonJones, 2005). A két állam demográfiai erôforrásai, gazdasági és katonai ereje messze meghaladja a közép-ázsiai régió lehetôségeit.

Bár jelen tanulmány fókusza Oroszország és Kína versengése Közép-Ázsiában, mindenképpen figyelmet érdemel, hogy a térség nem kizárólagosan a két említett nagyhatalom befolyásolási zónája. A Szovjetunió összeomlása utáni hatalmi úrt több potens ország is igyekezett kihasználni, leginkább a kétezres évektől kezdve. Egy időben erôteljesen jelen volt a térségben az USA, elsôsorban katonai jelenléttel. Motivációi Közép-Ázsia semlegesítése, az orosz és kínai befolyás ellensúlyozása, másrészt pedig a térség vallási radikalizációjának megakadályozása és Irán befolyásának semlegesítése volt. A térségi befolyásért folytatott játszma többi résztvevơje között találjuk Törökországot és Iránt, és bár sokkal korlátozottabb mértékben, de az Európai Uniót is. Kétségtelen ugyanakkor, hogy a térségre a legnagyobb hatást Oroszország és Kína gyakorolja, a térség politikai és gazdasági jövője e két nagyhatalom között fog eldôlni (Bendarzsevszkij, 2019).

Az elmúlt években Oroszország és Kína az eurázsiai régiót érintő geopolitikai stratégiáik megvalósítását kezdték el azzal a céllal, hogy a Közép-Ázsiát átszelő kereskedelmi és energiafolyosók segítségével a Kelet és Nyugat közötti gazdasági együttmúködést fejlesszék. Ennek a folyamatnak fontos részét mutatja az 1. ábra.

Az Eurázsiai Gazdasági Unió (EGU) megvalósítása jelenleg az egyik legnagyobb hatású kezdeményezés a kooperáció elósegítésére a régióban, melynek része egy, az együttmúködés politikai dimenzióinak fejlesztését célzó, több területre kiterjedô, nemzetek feletti keret létrehozása is, mely lehetôség kapcsán a közép-ázsiai országok komoly ellenérzést táplálnak. Ezzel szemben az Övezet és Út Kezdeményezés (Belt and Road Initiative, BRI) kínai stratégiája kifejezetten vonzó projektnek túnik, amely valamennyi közép-ázsiai országot bevon egy gazdasági haszonnal járó energia- és gazdasági hálózatba, mivel a kínaiak hatalmas beruházásai a térségi infrastruktúrák javítása és a nemzetgazdaság fejlesztése szempontjából egyaránt hasznosak. 1991 óta az egyes posztszovjet közép-ázsiai köztársaságok eltérố megközelítést alkalmaznak a regionális együttmúködési kezdeményezésekre és projektekre a különbözô gazdasági, politikai és biztonságpolitikai területeken: Kazahsztán, Kirgizisztán és Tádzsikisztán mindig támogatták és részt vettek a regionális együttmúködési kezdeményezésekben, míg Türkmenisztán és Üzbegisztán tartózkodtak az elkötelezôdéstôl.

Nyilvánvaló, hogy e két kooperációs projekt - amely nyilvánvalóan versenynek tûnik, de potenciálisan akár a szándékok egyesülésével is végzôdhet - végrehajtása komoly következményekkel jár majd a közép-ázsiai országok EU-val fennálló gazdasági kapcsolataira, kibővíti a komoly nyereséget termeló kelet-nyugati üzleti lehetôségeket, új kereskedelmi útvonalakat nyit meg, és végeredményben erôsíti az eurázsiai régió és az EU-tagállamok egymásrautaltságát. Ezenkívül ez a két geopolitikai stratégia befolyásolja a közép-ázsiai országok politikai és gazdasági fejlôdését és külpolitikájukat. 
Vasa László: Közép-Ázsia: Eurázsiai Gazdasági Unió vagy Övezet és Út?

\section{1. ábra: Közép-Ázsia energiafolyosói a szovjet idôkben és napjainkban}

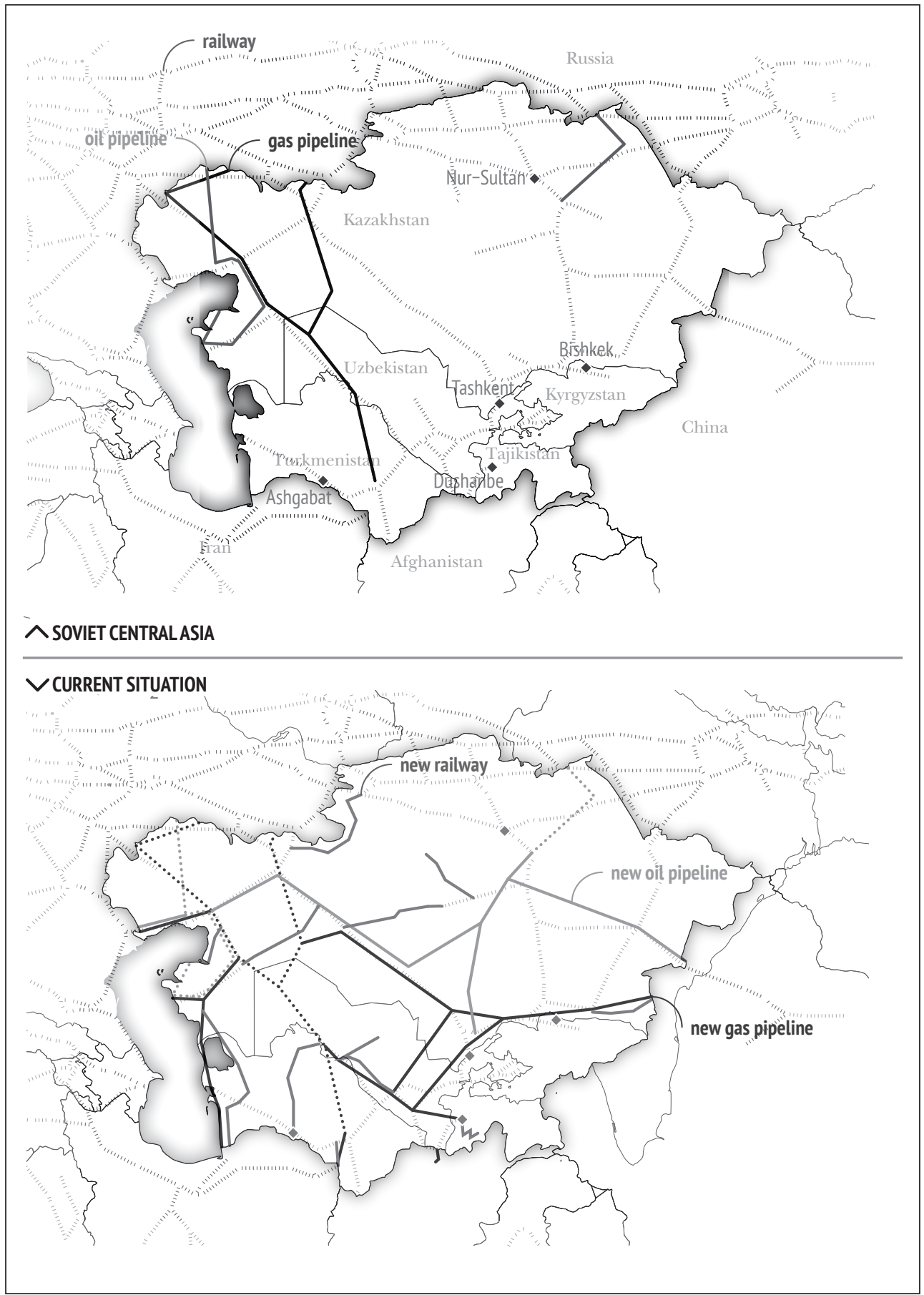

Forrás: www.iss.europa.eu/content/connecting-dots-challenges-eu-connectivity-central-asia 
Polgári Szemle $\cdot$ 16. évfolyam 1-3. szám

Kína és Oroszország Viszonya KözéP-Ázsiában

Az öt közép-ázsiai köztársaság 1991. évi függetlensége óta Oroszország és Kína - a két legerôsebb regionális geopolitikai szereplő - szoros kapcsolatokat alakított ki ezekkel az új államokkal annak érdekében, hogy stratégiai céljaikat elérjék a hirtelen átalakult regionális geopolitikai színtéren. A gazdasági, energiaügyi és geostratégiai célokon túlmenôen a biztonsági aggodalmak és a stabilitással kapcsolatos kérdések Oroszországot és Kínát közös platformra terelték a posztszovjet Közép-Ázsiában.

A Szovjetunió felbomlását követően, a posztszovjet államok függetlensége óta három szakasz jellemzi a kínai-orosz viszonyt az öt közép-ázsiai köztársaság kapcsán.

Az elsố szakasz a volt szovjet Közép-Ázsia függetlenségét követô elsố tíz évet fogja át (1991-2001). Oroszország és Kína önálló politikát folytatott Közép-Ázsiában, kétoldalú kapcsolataik javultak a hidegháború korábbi bizalmatlansága és feszültségei után. Oroszország stratégiai célja a politikai, gazdasági, katonai befolyása alá rendezendô „közel-külföld”, egyfajta pufferzóna kialakítása volt, az aktív bilaterális kapcsolatok fenntartása és a közép-ázsiai országok Moszkva által támogatott multilaterális gazdasági szervezetekbe történô bevonása révén (Közép-ázsiai Együttmúködési Szervezet, Central Asian Cooperation Organization - CACO, a katonai jellegú Kollektív Biztonsági Szerződés Szervezete, Collective Security Treaty Organization - CSTO, és a politikai alapú Független Államok Közössége, FÁK). Bár a rendszerváltáskor eredetileg az orosz külpolitika legfóbb célja a Nyugattal fenntartott kapcsolatok megerôsítése volt, és így a posztszovjet Közép-Ázsiát mint felvállalhatatlan gazdasági és politikai terhet sorsára hagyta, a regionális biztonságot és stabilitást fenyegetô veszélyekkel kapcsolatos késóbbi fejlemények (mint például a tádzsik polgárháború 1992 és 1997 között, vagy az afgán instabilitás és a lehetséges iszlamista felkelés) és az új, független országok fölötti hagyományos befolyás fenntartásának szándéka arra késztette Moszkvát, hogy kialakítsa és végrehajtsa a közép-ázsiai integrációs stratégiáját (Allison, 2004:286-288).

Ezen oroszországi kísérletekhez a közép-ázsiai államok különbözô módon viszonyultak, elsôsorban a gazdasági és politikai kérdések mentén: míg Kazahsztán, Kirgizisztán és Tádzsikisztán mindig részt vettek a Moszkva által támogatott nemzetközi szervezôdésekben, Üzbegisztán és Türkmenisztán nem bízott Oroszország hegemóniára törekvố integrációs politikájában. Putyin elnök hatalomra kerülésével Oroszország tovább fokozta a közép-ázsiai geopolitikai befolyásának helyreállítását célzó külpolitikai stratégiájának megvalósítását, amelynek valódi oka egyrészt az iszlám milíciák fegyveres támadásainak mint biztonságpolitikai kockázati tényezô felszámolásának kényszere Üzbegisztánban és a Fergána-völgyben 1999-2000-ben, másrészt a nyugati olajcégek által elnyert jelentôs kazah (Tengiz és Kasagan olajmezốk) koncessziók voltak. Mindezek szükségessé tették az orosz jelenlét megerôsítését Közép-Ázsiában.

Kína Közép-Ázsia-stratégiája az új köztársaságok függetlenségének elsố tíz évében elsôsorban három fố célra fókuszált:

1) a nemzetbiztonság és a regionális stabilitás garantálása; tekintettel a közös vallási, etnikai és kulturális gyökerekre, Kína attól tartott, hogy a nyugati határához közelebb álló független államok létrehozása a nyugat-kínai Hszincsiang régió ujgur lakosságát 


\section{Vasa László: Közép-Ázsia: Eurázsiai Gazdasági Unió vagy Övezet és Út?}

arra ösztönözheti, hogy támogassa a szeparatista tendenciákat, és követelje a Kínától való függetlenséget (Brugier, 2014);

2) politikai és gazdasági kapcsolatok fejlesztése; a közép-ázsiai köztársaságokkal mint új határ menti partnerekkel való kapcsolatok javítása a gazdasági és kereskedelmi kapcsolatok fejlesztése érdekében. Kína kétoldalú kapcsolatokat alakított ki elsôsorban a szomszédos Kazahsztánnal, Kirgizisztánnal és Tádzsikisztánnal, és rendezte a szovjet idôkból örökölt határkérdéseket. A mélyebb gazdasági kapcsolatok kialakítása viszonylag egyszerûnek bizonyult, mivel a kínai és a közép-ázsiai gazdaságok jól kiegészítették egymást: Kína nyersanyagokat (energia, vas és színesfémek, valamint ásványok) importált, és nagy piacot jelentett Közép-Ázsia országai számára, amelyek Kínából fogyasztási cikkeket és késztermékeket importáltak (Bugajski-Assenova, 2016:386-388);

3) az energiabiztonság megerốsitése; Kína energiaügyi együttmúködést alakított ki az olajban gazdag Kazahsztánnal, és a kínai energetikai cégek a kazah olajmezókbe kezdtek befektetni, azzal az egyértelmú stratégiai céllal, hogy új csôvezetéket építsenek a kazah olaj Kína felé történô szállításához, lehetôvé téve a kínai energiaimport diverzifikációját.

A Sanghaji Együttmúködési Szervezet (Shanghai Cooperation Organization, SCO) 2001-es létrehozása rávilágított a kínai-orosz közös szándékra a közép-ázsiai biztonsági térségben folytatott együttmúködés javítására az úgynevezett „három gonosz” (szeparatizmus, vallási szélsôségesség és terrorizmus) ellen. A regionális stabilitás biztosítása érdekében Oroszország és Kína megállapodtak abban, hogy létrehozzák ezt a regionális szervezetet, amelynek keretében a közép-ázsiai államokkal (kivéve Türkmenisztán) együttmúködés valósulhat meg (Burnashev, 2002:134). Annak ellenére, hogy Közép-Ázsiában komoly érdekellentétek voltak (és vannak), Oroszország és Kína normalizálta kapcsolatait a jószomszédságról, az együttmúködésról és a barátságról szóló szerzôdés 2001. júliusi aláírását követôen, amely kölcsönös bizalmon és egyenlőségen alapuló stratégiai partnerség, és célja a stratégiai együttmúködés a nemzetközi és regionális kérdésekben (Indeo, 2016).

A második szakaszban (2001-2005) az Egyesült Államok katonai jelenléte a térségben hozzájárult a geopolitikai érdekek stratégiai konvergenciáján alapuló kínai-orosz együttmúködés elômozdításához. Az afganisztáni amerikai katonai beavatkozást követôen az Egyesült Államok megerôsítette a katonai együttmúködést: Üzbegisztánnal a Karsi-Hanabad légibázis (más néven K2 légibázis) használatával, Kirgizisztánnal pedig a Manas légibázis igénybevételével. Oroszországot és Kínát nyilvánvalóan aggasztotta az akár hosszú távú amerikai katonai jelenlét Közép-Ázsiában: Moszkva nem örült, hogy a volt szovjet térségben megjelentek az amerikai katonai erók, és attól tartott, hogy a Közép-Ázsiával folytatott gazdasági és katonai együttmúködés fokozódása gyengítheti hagyományos és stratégiai befolyását a térségben. Kína szintén aggodalommal és gyanakodva figyelte az amerikai terveket a térség egyes országaiban, különös tekintettel arra, hogy a Manas légitámaszpont és a tádzsikisztáni katonai múveletek nemzetbiztonsági szempontból túl közel voltak a kínai határhoz.

Stratégiai geopolitikai helyzetükre tekintettel a közép-ázsiai országok sikeresen kihasználták a külsố szereplôk közötti versenyt, kiegyensúlyozva a kínai-orosz növekvő 
befolyást, elôsegítve a jövedelmezô gazdasági és katonai együttmúködést a NATO katonai erôivel, mely politikai és diplomáciai hátteret és támogatást is jelentett számukra. Mindazonáltal Oroszország és Kína eleinte tolerálta az amerikai katonai jelenlétet, mert ez segített megelôzni a legrosszabb afganisztáni forgatókönyv megvalósulását, így hozzájárult a térség biztonságához és stabilitásához (Congiu, 2016:35-37).

Az USA katonai jelenléte azonban nyilvánvalóan gyengítette a kínai-orosz befolyást Közép-Ázsiában, csökkentve a stratégiai szerepüket a térségben, ezért Oroszország és Kína 2003-ban stratégiát dolgozott ki a régióban való befolyásuk helyreállítására és kiterjesztésére, megerősítve a két- és többoldalú együttmúködéseket. Kétoldalú kapcsolataikat tekintve Kína stratégiája elsôsorban a közép-ázsiai köztársaságokkal folytatott gazdasági és energiaügyi együttmúködés elmélyítésére irányult, míg Oroszország a katonai együttmúködés megerôsítésére összpontosított; emellett az Egyesült Államok katonai jelenléte Közép-Ázsiában segített Oroszországnak abban, hogy stratégiai katonai lehetôségeket kapjon Kirgizisztánban (a Kant légibázisban, amely a CSTO-kooperációban múködik) és Tádzsikisztánban (állandó orosz bázis létrehozása Dusanbéban) (Cooley, 2008:66-68).

Az amerikai katonai erôk Közép-Ázsiából történô kiszorítása és a nyugati befolyás korlátozása a kínai-orosz közös stratégiai célrendszer mentén történt; ezt részben a SCO révén érték el, a Közép-Ázsia tagjaira gyakorolt stratégiai nyomás révén, meggyőzve ôket, hogy saját nemzeti érdekeiket és a régió stabilitását leginkább ez a regionális biztonsági szervezet segíti elő, nem pedig az USA-val való stratégiai partnerség (Djalili-Kellner, 2006). Kína és Oroszország jól ki tudta használni az Egyesült Államok és a közép-ázsiai köztársaságok közötti stratégiai kapcsolatok fokozatos leépülését, mivel a közép-ázsiai országok negatívan értékelték a nyugati nyomásgyakorlást az emberi jogok védelme és a demokratikus reformok kapcsán, ezeket belsô ügyeikbe történô beavatkozásként értelmezték. Emellett a posztszovjet térség „színes forradalmaiban” (Grúzia, Ukrajna és Kirgizisztán 2005-ben) vélhetôen játszott amerikai szerep is fokozta az általános bizalmatlanságot az Egyesült Államok geopolitikai stratégiájának valós térségi céljaival kapcsolatban (Dragneva-Wolczuk, 2014:12-15). 2005-ben kölcsönös védelmi megállapodás jött létre Moszkvával, 2006-ban pedig Üzbegisztán is csatlakozott az orosz vezetésú regionális szervezethez, a CSTO-hoz és az EurAsEC-hez (Frost, 2009). A színes forradalmak következményeként, a belsố biztonság megerôsítése és politikai hatalmuk megórzésének szándéka arra késztette a közép-ázsiai államvezetôket, hogy külpolitikájukat a két regionális szuperhatalom felé orientálják, amelyeket olyan megbízható biztonsági partnereknek tekintenek, amelyek képesek az ilyen fenyegetések visszaszorítására és a jelenlegi (politikai) helyzet fenntartására.

Miután elérték az Egyesült Államok katonai erejének régióból való távozását célzó közös célkitúzést, Oroszország és Kína megszilárdította befolyását Közép-Ázsiában, megnyitva a jelenleg is tartó harmadik fázist. A közép-ázsiai köztársaságok számára a NATO kivonulása egyben a kínai-orosz befolyást katonai, gazdasági, energetikai és politikai területen kiegyensúlyozó multivektorú külpolitikai stratégia végét is jelentette.

Ebben a harmadik szakaszban már felszínre kerültek Kína és Oroszország divergáló stratégiai céljai Közép-Ázsiában, amely számos feszültség lehetôségét hordozza 


\section{Vasa László: Közép-Ázsia: Eurázsiai Gazdasági Unió vagy Övezet és Út?}

magában, és egyben növeli a geopolitikai versengést, elsôsorban az energia és a gazdaság területén. Ez utóbbi összefügg Kínának korántsem csak Közép-Ázsiában, hanem a világ számos más térségében, például a szubszaharai afrikai országokban is erôteljesen megnyilvánuló törekvésével, hogy növekvô energia- és nyersanyagimportját beszerzési források tekintetében diverzifikálja (Erdei-Késmárki-Gally-Neszmélyi, 2017). Kína térségbeli gazdasági és kereskedelmi partneri szerepének erôsödése mellett - amely együtt járt Oroszország hagyományosan fontos szerepének fokozatos csökkenésével - Pekingnek történelmi lehetôséget jelentett a regionális energia sakktábláján a Közép-Ázsia és Kína közötti gázvezeték 2009-es megnyitása, amely egyben a türkmén gázkivitel orosz monopóliumának megszúnését is jelentette, ahogyan a kínai-kazah olajvezeték megépítése is tovább gyengítette az orosz kontrollt a közép-ázsiai energiaexporton, új feszültségpontot teremtve az orosz-kínai kapcsolatokban.

Ezen túlmenốen az SCO-n belül is nyilvánvalóvá vált a kínai-orosz geopolitikai versengés (Khan et al., 2020) a regionális szervezet jövôbeli fejlódésével kapcsolatban: Moszkva a katonai együttmúködést helyezi elôtérbe, és priorizálja a biztonsági kérdéseket, míg Peking célja az SCO kompetenciáinak és hatásának bôvítése gazdasági téren. 2007-ben a CSTO és az SCO egyetértési memorandumot írt alá a katonai és biztonsági együttmúködés fokozása érdekében. Ezt a megállapodást úgy lehet értelmezni, hogy Moszkva arra törekszik, hogy Kína teljes értékú katonai szövetségessé váljon; ennek célja azonban egyértelmúen az, hogy kontroll alatt tartsa a kínai hatalmi törekvéseket, és éreztesse Oroszország elsóbbségét a regionális biztonság területén (Gabuev, 2015). A közép-ázsiai köztársaságokkal folytatott katonai együttmúködés szintjén Kína valóban nem tud versenyezni Oroszországgal: Pekingnek nincs katonai bázisa a térségben (részben a közép-ázsiai közvélemény heves ellenállása miatt, mert félnek a potenciális kínai expanzionizmustól nemzeti területükön). Oroszország a kétoldalú katonai együttmúködésben és a CSTO tevékenységeiben részt vevő közép-ázsiai államok biztonságának fố garantálójaként jelenik meg: Oroszország az Eurázsia-régiót exkluzív befolyási területnek tekinti, amely a CSTO tevékenységein keresztül megvédi a régiót a külsố beavatkozásoktól. Így Moszkva a nyugati és a kínai befolyás ellensúlyaként jelenik meg a posztszovjet közép-ázsiai térségben.

$$
\begin{gathered}
\text { Az Eurázsiai Gazdas ági Unió } \\
\text { és az Övezet és Út Kezdeményezés }
\end{gathered}
$$

Ebben az átrendezôdô geopolitikai helyzetben mind Oroszország, mind Kína elindította saját geopolitikai stratégiai kezdeményezéseit, az Oroszország által támogatott Eurázsiai Gazdasági Uniót (EGU) és a Kína által támogatott Övezet és Út Kezdeményezést (Belt and Road Initiative, BRI). ${ }^{2}$

Az Eurázsiai Gazdasági Unió, amely formálisan 2015. január 1-jén alakult meg, egy 2000-ben megkezdett gazdasági integrációs folyamat utolsó szakasza (2. ábra). 1999ben Fehéroroszország, Kazahsztán, Kirgizisztán, Oroszország és Tádzsikisztán megállapodást írt alá a vámunióról és a közös gazdasági politikáról. A dokumentum az integráció három szintjét határozta meg: 1) az Eurázsiai Gazdasági Közösség (EurAsEC); 
2) Fehéroroszország, Kazahsztán és Oroszország közös gazdasági térsége és vámuniója (CU); 3) a gazdasági unió (Eurázsiai Gazdasági Unió - EGU, Eurasian Economic Union - EAEU). E folyamatok utolsó szakaszában a felek a közös piacok elônyeinek kihasználását várták a) harmonizált jogszabályokkal; b) egységes energia-, közlekedési és kommunikációs infrastruktúra kialakításával és közös szabványokkal; c) összehangolt adórendszerrel, és d) az áruk, szolgáltatások, a tốke és a munkaerô szabad mozgása által. Annak ellenére, hogy bizonyos közös piacok, különös tekintettel a stratégiai szempontból fontos termékekre, még mindig a megvalósítás szakaszában vannak, a tagállamoknak sikerült létrehozniuk egy jogi és múködési keretként felfogható intézményi struktúrát, és integrálni a tagállami piacokat (Ilyash-Vasa, 2019).

\section{2. ábra: Az Eurázsiai Gazdasági Unió}

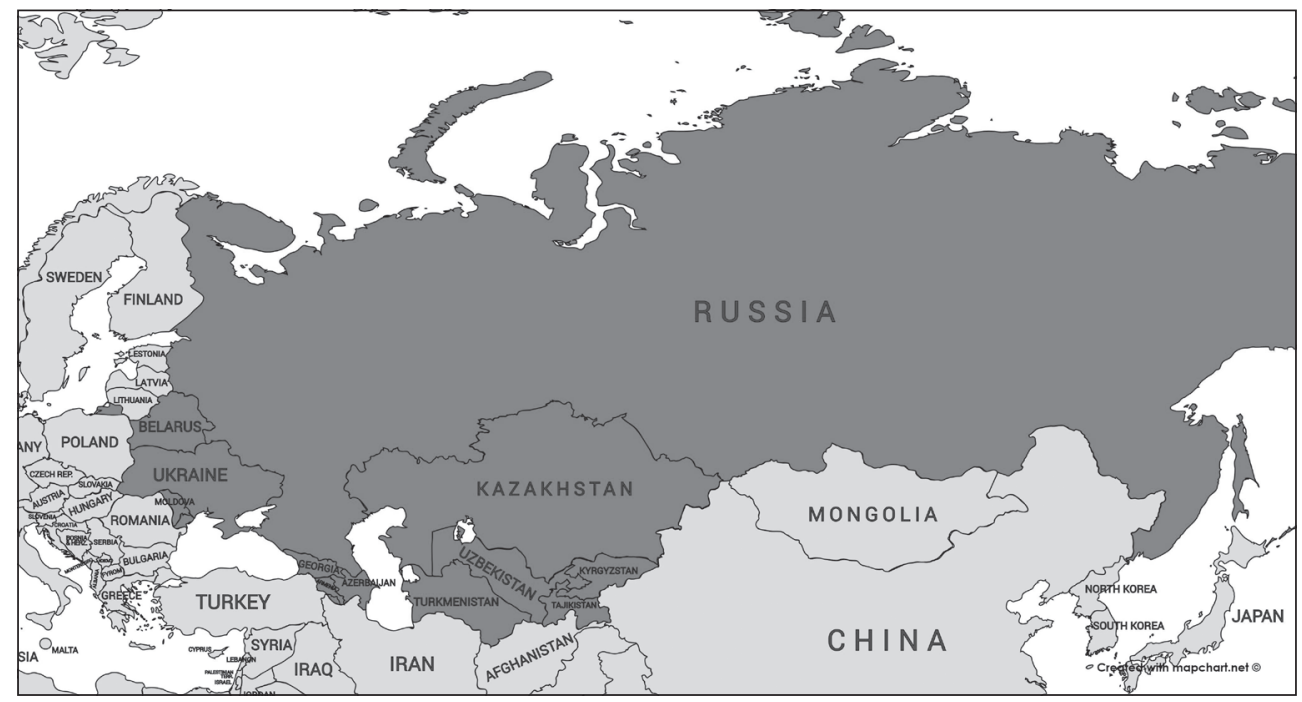

Forrás: www.nationstates.net

Az EGU-tól eltérôen az Övezet és Út Kezdeményezésnek (BRI), amelyet 2013-ban a Kínai Népköztársaság elnöke, Hszi Csin-ping javasolt, nincs átfogó intézményi kerete a céljai megvalósításához. Ennek ellenére a BRI együttmúködést tervez az olyan területeken is, mint a nemzeti politikák koordinálása, az infrastruktúra fejlesztése, a kereskedelem és a beruházások liberalizálása és egyszerúsítése, valamint a pénzügyi és kulturális együttmúködés. Az BRI-t a közép-ázsiai elit valójában még vonzóbbnak tekinti országaik számára, mint az EGU, mivel nem írja eló a szervezeti tagságot (Gyene, 2018).

Meglehetôsen nehéz összehasonlítani az EGU-t és az BRI-t. Az EGU egy döntéshozó és végrehajtó szervezetekkel rendelkezô, formálisan múködô nemzetközi szervezet, míg az BRI egy olyan befektetési program, amelynek tevékenysége kétoldalú megállapodásokon alapul. Mindkét kezdeményezés fontos célja a közép-ázsiai gazdasági kapcsolatok erôsítése. E tekintetben a két kezdeményezés bizonyos mértékben kiegé- 
3. ábra: Az Övezet és Út Kezdeményezés

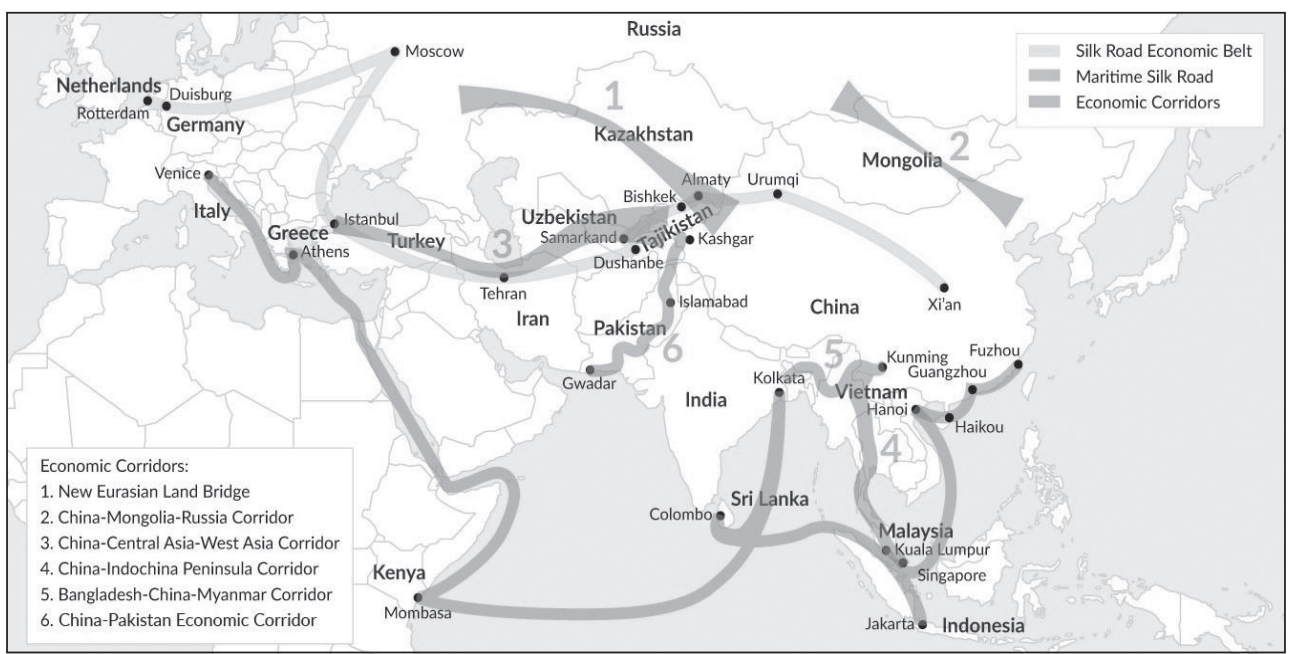

Forrás: www.gisreportsonline.com

szítheti egymást. Oroszországnak jelenleg nincs elegendô pénzügyi forrása nagyszabású regionális fejlesztési projektek megvalósítására, miközben Kína szinte minden területen jellemzốn az általa nyújtott hitelekból megvalósuló beruházásokat tervez. Jelenleg csak két közép-ázsiai ország tagja az EGU-nak (Kazahsztán és Kirgizisztán), míg a BRI-kezdeményezés mind az öt államot (Kazahsztán, Kirgizisztán, Üzbegisztán, Türkmenisztán, Tádzsikisztán) lefedi. Oroszországnak és Kínának eltérô érdekeik vannak a régió energiaforrásaival, ${ }^{3}$ az ipari termelés fejlesztésével és az áruk kereskedelmével kapcsolatban. Megjegyzendô, hogy mind az EGU-ban, mind a BRI-ben érintett államok vezetôi hangsúlyozzák, hogy az egyes országok közötti összeköttetés javítása a fố céljuk, és ennek érdekében létrehoznak bizonyos koordináló mechanizmusokat, a tények viszont azt mutatják, hogy a regionális elem tulajdonképpen hiányzik ezekben a kezdeményezésekben.

Az Eurázsiai Gazdasági Unió és az Övezet és Út Kezdeményezés a gyakran elemzett kezdeményezések, amelyek célja a tengeri kijáratoktól elzárt Közép-Ázsia kiváló közlekedési kapcsolatokkal rendelkezó régióvá való átalakítása (4. ábra). Az együttmúködés multilaterális formáit a regionális interakció és együttmúködési keretek felállítására tervezték. A két kezdeményezés területi határai átfedésben vannak, és lefedik az együttmúködés minden ágazatát, amelyek célja a régió összekapcsoltságának javítása.

Mind az EGU-, mind a BRI-együttmúködést kritizálták a részt vevő felek eróviszonyainak egyenlőtlensége miatt. A tagállamok közötti méretbeli eltérések olyan, befolyásoló államok méretéhez kapcsolódó aggályokhoz vezettek, amelyek szerint az EGU elôsegíti az orosz hegemóniát Közép-Ázsiában, miközben a BRI és az SCO alapot teremthetne a kínai dominanciához (Gatev-Diesen, 2016). Ugyanezen okokból hasznos lehet az EGU tagjainak egyesült, erôsebb tárgyalási partnerként fellépni Kínával szemben, Kína számára pedig mindez egy jó lehetôség az EGU egységes piacai felé. 
Polgári Szemle · 16. évfolyam 1-3. szám

4. ábra: Közép-Ázsia közlekedési hálózata az Övezet és Út Kezdeményezés kontextusában

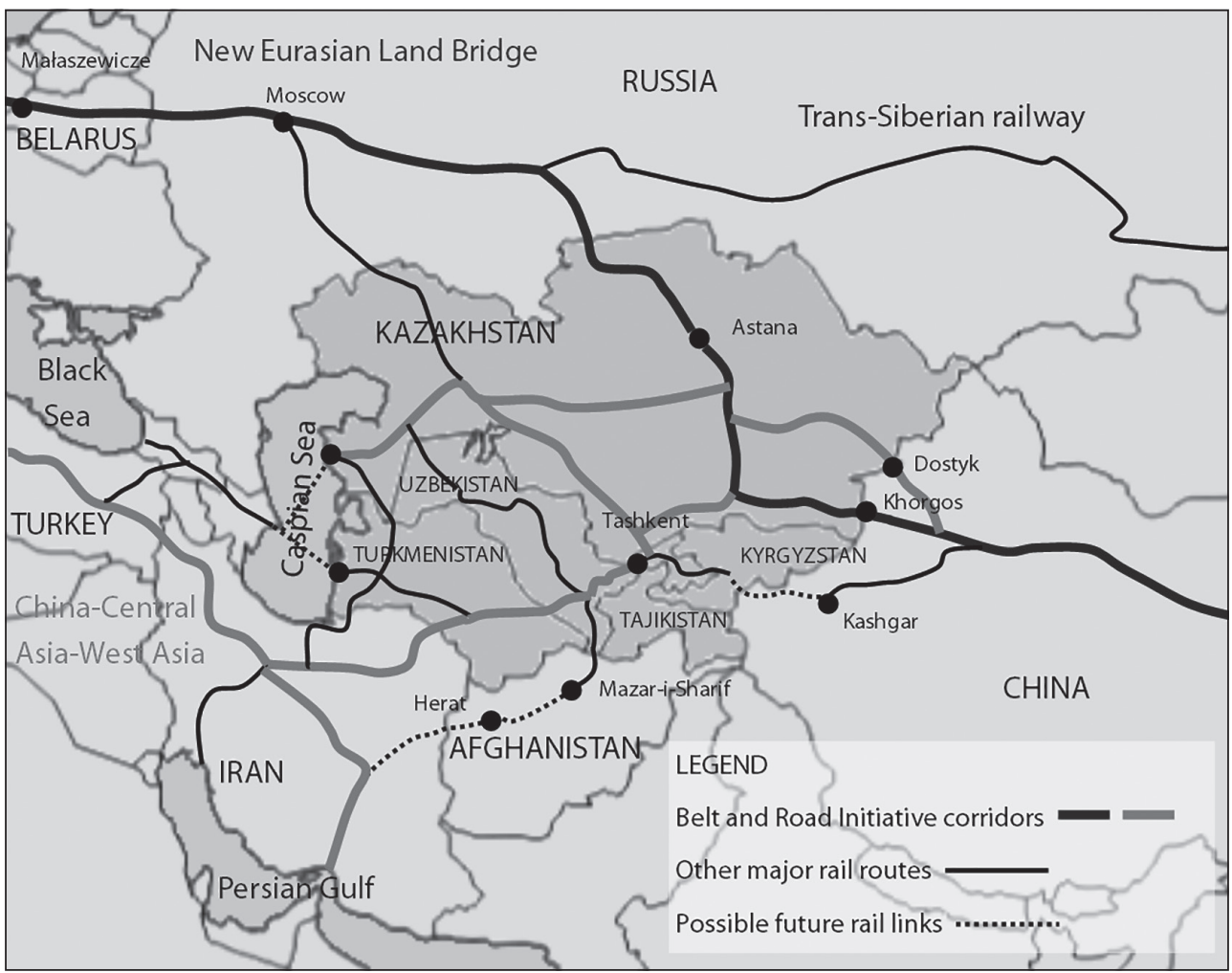

Forrás: www.europarl.europa.eu/RegData/etudes/BRIE/2019/637891/EPRS_BRI(2019)637891_EN.pdf

Az eurázsiai gazdasági integráció értékelésekor az orosz szakértôk megjegyezték, hogy az EGU egyik intellektuális problémája az, hogy Oroszország esetében mindig egyértelmú volt, mit épít, de arra soha nem kaptak választ, miért építi ezeket a struktúrákat (Bratersky, 2016). A BRI-projekt valódi szándékai és lehetséges következményei tehát messze túlmutatnak a gazdasági indokokon. Ebben az értelemben a BRI támogatói tanulhatnak az EGU tapasztalataiból, azaz, hogy a nem gazdasági célokat is világosan be kell mutatni a széles nyilvánosságnak, és célszerú gondoskodni a kezdeményezések társadalmi elfogadásáról a csatlakozó országokban.

\section{Az INTEGRÁGIÓK INTEGRÁGIÓJA}

„A negyedik ipari forradalom korszakába lépett világgazdaság dinamikája felvetette az »integrációk integrálása « kérdését; a gazdasági növekedés közös pontjainak kialakulása az Eurázsiai Gazdasági Unió és a »Nagy selyemút gazdasági öve « között hatalmas kilátásokkal rendelkezik". ${ }^{4}$

A rivalizálás rövid idôszaka után Oroszország és Kína 2015 májusában hozta tetô alá az EGU és a BRI közötti fokozott együttmúködésról szóló megállapodást. 2017. ok- 
Vasa László: Közép-Ázsia: Eurázsiai Gazdasági Unió vagy Övezet és Út?

tóber 1-jén Kína kereskedelmi minisztere, Csung San és az EGU Gazdasági Bizottság együttes nyilatkozatot írt alá Hangcsouban az Eurázsiai Gazdasági Unió és Kína közötti kereskedelmi-gazdasági együttmúködésről. ${ }^{5}$ 2018. január 17-én az EGU Gazdasági Bizottsága jóváhagyta az EGU és a Kínai Köztársaság vámhatárain áthaladó, nemzetközi szállítmányokra és jármúvekre vonatkozó információcserérôl szóló megállapodás tervezetét. A megállapodás felgyorsítja az EGU országaiba és Kínába, valamint a tranzitszállításra behozott áruk vámkezelési eljárásait. ${ }^{6}$

Jelenleg 39, prioritást élvezó infrastrukturális projekt múködik az EGU-BRI-koordináció keretében: Örményország: 2, Fehéroroszország: 3, Kirgizisztán: 12, Oroszország: 12, Kazahsztán: 10. Megjegyzendő, hogy a listából 20 projekt kapcsolódik a vasúti közlekedési ágazathoz (Enikeeva, 2017).

Kína tapasztalata az EGU-országokkal mint csoporttal való kapcsolattartásban a Sanghaji Együttmúködési Szervezeten (SCO) alapul. Az EGU összes tagja részt vesz az SCO munkájában (Fehéroroszország megfigyelő állam, Örményország pedig párbeszédpartner). A szervezetet 2001-ben alapította Kazahsztán, Kína, Kirgizisztán, Oroszország és Tádzsikisztán. Az SCO és az EGU-előd EurAsEC közötti kapcsolatok 2006-ban kezdődtek meg az egyetértési nyilatkozat aláírásával. A fentiekben említettek szerint az EGU-t eredetileg gazdasági uniónak tekintették, amely a tagállamok további politikai összehangolásához vezetett. Ezzel szemben az SCO elôször béketeremtô és határellenôrzési mechanizmusként jelent meg. A két szervezet intézményi felépítése szintén meglehetôsen eltérő, mivel az EGU két nemzetek feletti intézményt (az Eurázsiai Gazdasági Bizottságot és a Bíróságot) foglal magában, míg az SCO államközi szinten múködik, rendszeres üléseken keresztül. Kína már próbálkozott a nagyobb gazdasági integráció elôsegítésével az SCO révén, de korlátozott sikerrel, mivel a szervezet továbbra is elsôsorban a biztonsági kérdésekre összpontosított. Mivel Kína továbbra is támogatja az eurázsiai gazdasági integrációt, amelybe egyes EGU-államok is belekerülnek, egyes vélemények szerint az EGU és az SCO közötti további koordinációt ösztönözni kell (Yu, 2015). Például 2015-ben az EGU és az SCO közös üzleti fórumot tartott Szentpéterváron, ahol kezdeményezték a két szervezet tagjai közötti közös digitális tér kialakítását. ${ }^{7}$ A SCO vezetôi a 2016. évi csúcstalálkozón megerôsítették a BRI támogatását, és kifejezték érdekloodésüket az Új Selyemút mentén folytatott további együttmúködés fejlesztésére különféle területeken: közegészségügy, tudomány és technológia, oktatás, környezetvédelem, sport, turizmus és az oktatás, valamint a kulturális és természeti örökség megőrzése. ${ }^{8}$ Egyes szakértôk úgy vélik, hogy az SCO (elsôsorban biztonságorientált szervezet) és az EGU (gazdasági integráció) közötti érdemi együttmúködés létrehozására irányuló jelentôs kísérletek végül átfogó Selyemút-unió létrehozásához vezethetnek (Kembayev, 2016).

A Kína és az EGU közötti gazdasági együttmúködés már a BRI bejelentése előtt megkezdődött. Az EGU Bizottság és a MOFCOM (Ministry of Commerce, Kína) 2012. december 6-án egyetértési megállapodást kötött a kereskedelem területén folytatott együttmúködésról. ${ }^{9} 2014$ végén hoztak határozatot az EGU és Kína között az átfogó termék- és szállítóeszköz-cserére vonatkozó megállapodás megkötésérôl szóló 
hivatalos tárgyalások megkezdésérôl. ${ }^{10}$ Az EGU Bizottság és a MOFCOM 2015 májusában kiadott együttes nyilatkozatban bejelentette a Kína és az EGU közötti kereskedelmi és gazdasági együttmúködési megállapodás megkötésére irányuló tárgyalások megkezdését. ${ }^{11}$ Ugyanebben a hónapban Oroszország és Kína együttes nyilatkozatot adott ki az EGU és a BRI együttmúködésével kapcsolatban, amelyben Oroszország támogatását fejezte ki a BRI irányában, míg Kína egyetértett az EGU gazdasági integrációjának fejlesztésére irányuló orosz erőfeszítésekkel. ${ }^{12}$ A felek megállapodtak abban, hogy kétoldalú szinten, valamint az SCO-platformon keresztül múködnek együtt. A közös nyilatkozatban az alábbi együttmúködési irányokat határozták meg: 1) a kereskedelem és a beruházások megkönnyítése; 2) közös beruházási projektek; 3) az infrastruktúra összekapcsolhatóságának javítása; 4) az EGU és Kína közötti hoszszú távú szabadkereskedelmi megállapodás ${ }^{13}$; 5) a kkv-k támogatása; 6) a nemzeti valutában történő fizetések megkönnyítése; 7) együttmúködés az ázsiai infrastruktúra-beruházási bankon, a Selyemút Alapon, az SCO bankközi konzorciumon belül; 8) a globális kereskedelem és a beruházások irányítása. Putyin elnök 2016. júniusi pekingi látogatása során mindkét fél megerôsítette a BRI és az EGU együttmúködése iránti elkötelezettségét. ${ }^{14}$

A BRI-EGU-párbeszéd gyors fejlődése ellenére a szakértők felhívták a figyelmet Oroszország és Kína eltérô érdekeire a BRI kapcsán. Oroszországban a Selyemutat hagyományosan keleti és nyugati összekötő közlekedési infrastruktúrának tekintik, ahol Oroszország kulcsszerepet játszik a világ e két részét összekötô hídként, de Kína növekedésével egy erôs ázsiai vektor is megjelent (Sakwa, 2016). Kína számára azonban a BRI elsôsorban „öv”, nem pedig „út”, vagyis a gazdasági fejlôdés és a jólét térségét jelenti, ahol a magasan fejlett államok intenzív kereskedelmet folytatnak (Makarov-Sokolova, 2016). Amiben a 21. századi Selyemút a középkoritól különbözik, hogy ma ez az út más politikai és gazdasági célokkal rendelkezô szuverén államokon halad keresztül. Ennek eredményeként azon kevés kérdés egyike, amelyet ezek a közép-eurázsiai államok egyhangúlag támogattak, a határigazgatás fejlesztése volt (Diener, 2015). Mivel a BRI alapvetôen a határokon átnyúló különféle áramlások (áruk, szolgáltatások, tôke és emberek) növekedésén alapszik, ez óriási kihívást fog jelenteni azoknak az államoknak, amelyek hajlanak területi szuverenitásuk megvédésére. Meg kell jegyezni azt is, hogy az EGU létrehozása a WTO szabályain alapult, és az EU intézményi integrációs modelljét használták mintaként (EGU Bizottság és EGU Bíróság) egy majdani, EU-val közös szabadkereskedelmi övezet érdekében (Kukushkina-Ostrovskaya, 2013). Az EU és Kína kereskedelmének kiterjesztésével az EGU közös gazdasági térsége elveszítheti értelmét. A BRI sikere azonban a jó Oroszország-Kína-kapcsolatokon is alapul. Meg kell jegyezni, hogy az Oroszország és Kína közötti jelenlegi szívélyes kapcsolatok ellenére Kína növekvô hatalma és Oroszországgal összehasonlítva túlzott gazdasági képességei növekvô hatalmi egyenlőtlenségeket teremtenek, és kihívást jelent az orosz-kínai interakció egyensúlyainak fenntartása (Wilson, 2016).

Az EGU-együttmúködéshez nem csatlakozó, más posztszovjet államok (Grúzia, Moldova, Ukrajna, Azerbajdzsán, Üzbegisztán, Türkmenisztán) indokainak értékelé- 
Vasa László: Közép-Ázsia: Eurázsiai Gazdasági Unió vagy Övezet és Út?

sekor figyelembe kell venni az orosz befolyás elkerülésére tett folyamatos kísérleteiket. Ezen államok többségénél ugyanakkor az orosz hatás kivédhetetlen, így elkerülhetetlenül részt vesznek valamiféle Oroszország által vezetett vagy támogatott gazdasági integrációban vagy annak regionális kezdeményezéseiben (Korosteleva, 2015). Mindazonáltal a fenti országok mindegyike kifejezte érdeklódését a BRI-projektekben való részvétel iránt, mivel ebben az összefüggésben e folyamat intézményesítése nagyobb stabilitást biztosít majd a posztszovjet államok regionális politikájában, de nem szab feltételeket (Skriba, 2014).

Mivel a BRI az összes EGU-tagot magában foglalja, törvényszerú e két gazdasági együttmúködés és az integrációs platform kölcsönhatása. Szakértôk az EGU fejlôdésének különféle irányait körvonalazták a BRI mentén, például: az eurázsiai közlekedési és logisztikai infrastruktúra integrációja, a határokon átnyúló ipari együttmúködés megerôsítése, és a gazdasági integráció fokozása az átfogó eurázsiai unió létrehozásáig (Makarov-Sokolova, 2016).

A tényleges céljaitól függetlenül az „integrációk integrációja” a BRI és az EGU esetében valóság, és ösztönözni kell az ezek együttmúködéséról folytatott további tudományos vitát.

\section{KÖVETKEZTETÉSEK}

Az EGU és az BRI elindítását követôen Oroszország és Kína erôsen motiváltak abban, hogy erôsítsék jelenlétüket és befolyásukat Közép-Ázsiában.

A közép-ázsiai energia- és közlekedési infrastruktúra fejlesztésére irányuló hatalmas kínai beruházások azt jelentik, hogy Kína stratégiai igényeinek megfelelóen alakítja át a régió viszonyait. Kína számára Közép-Ázsia a kereskedelem és az energia szárazföldi folyosóját jelenti, amely lehetôvé teszi Peking számára a gazdasági stratégia diverzifikálását, csökkentve a tengeri folyosó jelentôségét.

A regionális integrált kereskedelem és együttmúködés előmozdítása érdekében a BRI-projekt vonzóbbnak túnik a közép-ázsiai köztársaságok számára, mint az EGU, fốleg azért, mert a kínai kezdeményezés nem ír elô tagságot, és nem szervezet, hanem beruházási program; olyan infrastruktúrák fejlesztése, amelyek elôsegíthetik a közép-ázsiai, tengeri kijárattal nem rendelkezô országok kapcsolódását a globális piacokhoz és értékláncokhoz.

Ezzel szemben az EGU merev szervezetnek túnik, amelyen belül Oroszország gyakran veti fel azt a gondolatot, hogy szupranacionális politikai szervezetté alakítsák át, egységes valutával, összekapcsolva és összehangolva a külpolitikákat is. A közép-ázsiai államok tartanak ettôl, és következetesen elutasítják ezt az orosz felvetést, és ez egyben a kínai kezdeményezések felé tereli ôket.

Ezenkívül Oroszország jelenleg nem képes teljesíteni az ígéretét, mivel nehézségekbe ütközik a gazdasági előnyök megígért biztosítása, amelyet annak érdekében kínáltak fel, hogy meggyôzzék az EGU-csatlakozástól vonakodó országokat (Kirgizisztán és mostanában Tádzsikisztán). Nyilvánvaló, hogy ilyen módon az EGU elveszíti befolyásoló erejét. 
Ugyanakkor azt is észre kell vennünk, hogy Kína növekvô aktivitását a középázsiai közvélemény aggodalommal figyeli, és a pekingi hosszú távú területi expanziós és beavatkozási szándékok fenyegetése arra készteti a közép-ázsiai országokat, hogy korlátozzák az együttmúködést, még akkor is, ha középtávon a kínai beruházások régióban gyakorolt hatásai tovább ösztönzik a kereskedelmi és az energiaügyi együttmúködést.

A közép-ázsiai köztársaságok számára az Oroszország és Kína közötti kiújult verseny hozadékokkal járhat, lehetôvé téve számukra a térségben a kínai-orosz célok kiegyensúlyozását és stratégiai elônyök elérését. Viszont a Moszkva és Peking közötti közeledés hosszú távon hatással lehet a független külpolitikák kialakulására, mivel az egész régió ezen erôteljes geopolitikai szereplôk hatása alatt áll.

Oroszország pénzügyi nehézségei és a régióba való beruházás képtelensége átfordíthatja Moszkva stratégiáját: valójában Moszkva élvezheti a Peking által támogatott regionális közlekedési infrastruktúrák elônyeit az integrált regionális piac előmozdítása érdekében. Következésképpen Oroszország lemondhat a Moszkva által vezetett gazdasági együttmúködés előmozdítására irányuló törekvéseirôl, az EGU és a BRI közötti koordinációra és együttmúködésre összpontosítva. Ebben az esetben Oroszországnak kezelnie és rendeznie kell bizonyos torzulásokat, enyhítve a protekcionista intézkedéseket, és meg kell szüntetnie a szabadkereskedelmi megállapodások végrehajtásának akadályait is. Vámunióként az EGU korlátozza a tagok azon képességét, hogy különálló kereskedelmi megállapodásokat kössenek, de továbbra is szabadon köthetnek egyéb jelentós megállapodásokat (például a megújított partnerségi és együttmúködési megállapodást Kazahsztán és az EU között 2015-ben).

A regionális együttmúködés szempontjából mindkét stratégiát külsô szereplők támogatták, akik elsôsorban stratégiai igényeik mentén mozognak, és nem feltétlenül céljuk Közép-Ázsia belsô kereskedelmi és a politikai együttmúködésének fokozása. Úgy tûnik, hogy a régió országai csak a saját nemzeti céljaik megvalósítása érdekében kívánnak integrált regionális piacot fejleszteni, miközben a történelemból örökölt konfliktusok, amelyek hatással vannak a határokon átnyúló kapcsolatokra (vízgazdálkodás, enklávék, politikai rivalizálások, gyengén ellenôrzött határok, amelyek lehetôvé teszik az illegális kereskedelmet és a terroristák fegyveres behatolását), megoldatlanok maradnak.

A régió két legnagyobb integrációs kezdeményezése kiegészíti egymást, és egyben versengést is jelent Kína, Oroszország és a közép-ázsiai államok közötti együttmúködés jellegétôl és sajátos területétôl függóen. Az EGU és a BRI mind közvetlenül, mind közvetetten szövetségbe tereli a közép-ázsiai országokat, és köti óket a nagyobb hatalmak akaratához, amelyek tulajdonképpen kikényszerítik az együttmúködést az eurázsiai kontinensen. Azonban ezekben az integrációs kezdeményezésekben hiányzik a valódi regionális elem. Jól múködô regionális mechanizmus nélkül, amely lehetôvé teszi a tagállamok számára az érzékeny kérdések kezelését is, az EGU-n és a BRI-n belüli kapcsolatok könnyen veszélybe kerülhetnek. 


\section{Vasa László: Közép-Ázsia: Eurázsiai Gazdasági Unió vagy Övezet és Út?}

\section{JEGYZETEK}

1 Az EU-terminológia is ezt a kategorizálást követi: www.europarl.europa.eu/factsheets/en/sheet/178/ central-asia.

2 A program hivatalos neve nem tisztázott; az angol „One Belt, One Road” (Egy Övezet, Egy Út) és a „Silk Road Economic Belt” (Selyemút Gazdasági Övezet) elnevezés egyaránt használatban van. A kínai kormányzat az utóbbi idôben a „Belt and Road Initiative” (BRI) (Övezet és Út Kezdeményezés) nevet használja.

3 Bôvebben: www.worldbank.org/en/news/feature/2019/03/11/belt-and-road-initiative-in-central-asiaand-the-caucasus, illetve a Külügyi Szemlében megjelent írás Gyene Páltól (Gyene, 2018).

4 Idézet Nazarbajev akkori kazah elnök 2016. évi Astana Economic Forumon tartott beszédéből: http:// kremlin.ru/events/president/news/52178.

5 https://tass.com/economy/968315.

6 www.inform.kz/ru/kollegiya-eek-odobrila-proekt-soglasheniya-mezhdu-eaes-i-kitaem_a3124398.

7 Eurasian Economic Commission, Development of common digital space opens a new dimension of cooperation between Eurasian Economic Union and Shanghai Cooperation Organisation, www.eurasiancommission.org/ru/nae/news/Pages/18-06-2015-1.aspx.

8 Information Report on the Outcomes of the Meeting of the Council of Heads of Member States of the Shanghai Cooperation Organization (23-24 June 2016, Tashkent, Uzbekistan), www.mfa.uz/en/press/ scouzbekistan/sconews/7738/.

9 Memorandum of Cooperation in Trade Matters between the Eurasian Economic Commission and the Ministry of Commerce of the People's Republic of China (6 December, 2012), www.eurasiancommission.org/ru/act/trade/dotp/memorandymi/Documents/Mem4.pdf.

10 Eurasian Economic Commission, Decision on initiation of negotiations with the People's Republic of China regarding conclusion of an agreement on exchange of information regarding goods and vehicles of international carriage carried across customs borders between the customs union and the People's Republic of China (7 October, 2014), https://docs.eaeunion.org/docs/en-us/0143556/clcd_07102014_186.

11 Joint Statement of the Eurasian Economic Commission and the Ministry of Commerce of the People's Republic of China (8 May 2015), www.eurasiancommission.org/ru/act/trade/dotp/SiteAssets/dostup/6.1.\%20\%D0\%A1\%D0\%BE\%D\%B2\%D0\%BC.\%D0\%B7\%D0\%B0\%D1\%8F\%D0\%B2\%D0\%BB\%D0 \%B5\%D0\%BD\%D0\%B8\%D0\%B5_\%D0\%A0\%D0\%A3\%D0\%A1.pdf.

12 Joint Statement of the Russian Federation and the People's Republic of China on Cooperation in Conjugation of Construction of the Eurasian Economic Union and the Silk Road Economic Belt (8 May 2015), http://kremlin.ru/supplement/4971.

13 Egyes vélemények szerint a BRI közép-, illetve hosszú távú célja szabadkereskedelmi övezet létrehozása (Zeng, 2016).

14 Ministry of Foreign Affairs of the People's Republic of China, Xi Jinping Holds Talks with President Vladimir Putin of Russia Both Heads of State Stress Unswerving Commitment to Deepening China-Russia Comprehensive Strategic Partnership of Coordination (25 June 2016), www.fmprc.gov.cn/mfa_eng/ zxxx_662805/t1375791.shtml. Memorandum of Understanding on cooperation in the field of competition policy and anti-monopoly regulation. See Eurasian Economic Commission, EEC Minister Nurlan Aldabergenov signed a Memorandum of Mutual Understanding on antitrust policy and antitrust regulation with the National Development and Reform Commission of China in Beijing (16 June 2016), www. eurasiancommission.org/en/nae/news/Pages/16-06-2016-3.aspx.

\section{FELHASZNÁLT IRODALOM}

Allison, Roy (2004): Strategic Reassertion in Russia's Central Asia Policy. International Affairs, Vol. 80, No. 2, https://doi.org/10.1111/j.1468-2346.2004.00383.x.

Armitage, Richard - Nye, Joseph (2007): CSIS Commission on Smart Power: A Smarter, More Secure America. Center for Strategic and International Studies, www.innovations.harvard.edu/csis-commission-smart-power-smarter-more-secure-america. 
Baldwin, David A. (1985): Economic Statecraft. Princeton University, Princeton.

Bendarzsevszkij Anton (2019): Az „új nagy játszma” Közép-Ázsiában. PAGEO Geopolitikai Kutatóintézet, www. geopolitika.hu/hu/2019/01/22/az-uj-nagy-jatszma-kozep-azsiaban/.

Bratersky, Maxim (2016): Isolationism Versus Geopolitics: The Dual Role of the Eurasian Economic Union in Global Governance. International Organisations Research Journal, Vol. 11, No. 2, 58-70, https://doi. org/10.17323/1996-7845-2016-02-58.

Brugier, Camille (2014): China's Way: the New Silk Road. European Union Institute for Security Studies, Brief Issue 14, www.iss.europa.eu/content/china\%E2\%80\%99s-way-new-silk-road.

Bugajski, Janusz - Assenova, Margarita (2016): Eurasian Disunion. Russia's Vulnerable Flanks. The Jamestown Foundation, Washington DC.

Burnashev, Rustam (2002): Regional Security in Central Asia: Military Aspect. In: Rumer, B. (ed.): Central Asia: a Gathering Storm? M. E. Sharpe, London.

Congiu, Francesca (2016): China 2015: Implementing the Silk Road Economic Belt and the 21st Century Maritime Silk Road. In: Torri, Michelguglielmo - Mocci, Nicola (eds.): The Chinese-American Race for Hegemony in Asia. Viella, Rome, 19-52.

Cooley, Alexander (2008): U.S. Bases and Democratization in Central Asia. Orbis, Vol. 52, No. 1, 65-90, https://doi.org/10.1016/j.orbis.2007.10.004.

Dani, A. H. et al. (2005): History of Civilizations of Central Asia. Unesco, Paris.

Diener, Alexander C. (2015): Parsing Mobilities in Central Eurasia: Border Management and New Silk Roads. Eurasian Geography and Economics, Vol. 56, No. 4, 376-404, https://doi.org/10.1080/15387216. 2015.1078736.

Djalili, Mohammed - Kellner, Thierry (2006): Geopolitique de la nouvelle Asie Centrale: de la fin de l'URSS à l'apres-11 septembre. PUF, Paris.

Dragneva, Rilka - Wolczuk, Kataryna (2014): Eurasian Economic Integration: Institutions, Promises and Faultlines. The Geopolitics of Eurasian Economic Integration. LSE, London.

Enikeeva, Zalina (2017): EAEU and Silk Road Economic Belt: Is It Really a Win-Win Cooperation? The Case of Central Asia. Trade Policy, Vol. 4, No. 12.

Erdei-Késmárki-Gally, Szilvia - Neszmélyi, György (2017): Regional Development in the World - China's Role in Africa. Romanian Review of Regional Studies, Vol. 13, No. 1, 13-26, http:/ /rrrs.reviste.ubbcluj.ro/ site/arhive/Artpdf/v13n12017/RRRS13120172.pdf.

Frost, Alexander (2009): The Collective Security Treaty Organization, the Shanghai Cooperation Organization, and Russia's Strategic Goals in Central Asia. The China and Eurasia Forum Quarterly, Vol. 7, No. 3, 84-92.

Gabuev, Alexander (2015): Eurasian Silk Road Union: Towards a Russia-China Consensus? The Diplomat 5 June, http:/ / thediplomat.com/2015/06/eurasian-silk-road-union-towards-a-russia-china-consensus/.

Gatev, Ivylo - Diesen, Glenn (2016): Eurasian Encounters: the Eurasian Economic Union and the Shanghai Cooperation Organisation. European Politics and Society, Vol. 17, o. 1, 133-150, https://doi.org/10.1080 /23745118.2016.1171364.

Gyene Pál (2018): Kína gazdasági felemelkedése és az „Új Selyemút” percepciói Közép-Ázsiában. Külügyi Szemle, 17. évf., 3. sz., 99-115.

Ilyash György - Vasa László (2019): Az Eurázsiai Gazdasági Unió helyzete és kilátásai. Külügyi Szemle, 18. évf., 4. sz., 67-85.

Indeo, Fabio (2016): The Eurasian Economic Union and the Silk Road Economic Belt: the Impact of the Sino-Russian Geopolitical Strategies in the Eurasia Region. Working Paper No. 5, Center for Energy Governance and Security, EGS Korea, Hanyang University.

Kembayev, Zh. (2016): Towards a Silk Road Union? Chinese Journal of International Law, Vol. 15, No. 3, 691-699, https://doi.org/10.1093/chinesejil/jmw022.

Khan, Muhammad A. et al. (2020): Asymmetric Impact of Institutional Quality on Tourism Inflows Among Selected Asian Pacific Countries. Sustainability, Vol. 12, No. 3, https://doi.org/10.3390/su12031223.

Korosteleva, Elena (2015): Belarus Between the EU and Eurasian Economic Union. In: Dutkiewicz, Piotr Sakwa, Richard (eds): Eurasian Integration. The View from Within. Routledge, New York, 111-125. 


\section{Vasa László: Közép-Ázsia: Eurázsiai Gazdasági Unió vagy Övezet és Út?}

Kukushkina, Julia - Ostrovskaya, Elena (2013): Current Issues and Prospects of Eurasian and European Economic Integration. International Organisations Research Journal, Vol. 8, No. 4, 214-228.

Makarov, Igor - Sokolova, Anna (2016): The Eurasian Economic Union and the Silk Road Economic Belt: Opportunities for Russia. International Organisations Research Journal, Vol. 11, No. 2, 40-57, https://doi. org/10.17323/1996-7845-2016-02-40.

Nagy Szovjet Enciklopédia (2012): Az 1926 és 1990 közötti kiadások javított, 2012-es elektronikus verziója, https://slovar.cc/enc/bse/2057489.html.

Sakwa, Richard (2016): How the Eurasian Elites Envisage the Role of the EEU in Global Perspective. European Politics and Society, Vol. 17, No. 1, 4-22, https://doi.org/10.1080/23745118.2016.1171038.

Skriba, Andrei (2014): Challenges of Eurasian Integration after the Ukrainian Crisis. International Organisations Research Journal, Vol. 9, No. 3, 96-111.

Treverton, Gregory F. - Jones, Seth G (2005): Measuring National Power. Rand Corporation, www.rand.org/ content/dam/rand/pubs/conf_proceedings/2005/RAND_CF215.pdf.

Yu, Bin (2015): The Shanghai Cooperation Organisation, China and Eurasian Integration. In: Dutkiewicz, Piotr - Sakwa, Richard (eds): Eurasian Integration. The View from Within. Routledge, New York, 256-273.

Wilson, Jeanne L. (2016): The Eurasian Economic Union and China's Silk Road: Implications for the Russian-Chinese Relationship. European Politics and Society, Vol. 17, No. 1, 113-132, https://doi.org/10.108 0/23745118.2016.1171288.

Zeng, Lingliang (2016): Conceptual Analysis of China's Belt and Road Initiative: A Road towards a Regional Community of Common Destiny. Chinese Journal of International Law, Vol. 15, No. 3, 517-541, https:// doi.org/10.1093/chinesejil/jmw021. 